\title{
OS CAÇADORES DO RIOZINHO DO ANFRÍSIO: SABERES E PRÁTICAS CULTURAIS ENTRE NARRATIVAS E IMAGENS
}

Flávio Bezerra Barros ${ }^{1}$

\section{RESUMO}

$\mathrm{O}$ artigo apresenta os saberes tradicionais e as práticas culturais associadas à atividade da caça desenvolvida por beiradeiros da Reserva Extrativista Riozinho do Anfrísio, em Altamira, Pará. O texto se desenvolve a partir de uma perspectiva etnográfica e do ponto de vista metodológico seguiu as orientações das entrevistas abertas e observação participante. A caça no contexto estudado se constitui como uma das principais atividades produtivas dos agentes sociais e se apresenta permeada de elementos simbólicos. Curupira, Mapinguari e Matinta Pereira são exemplos das principais entidades sobrehumanas que atuam regulando a ação dos caçadores. Os animais caçados são apropriados de inúmeras maneiras, sendo úteis na alimentação, na preparação de remédios e em práticas de magia.

\section{PALAVRAS-CHAVE}

Conservação da biodiversidade. Cosmologia. Povos e comunidades tradicionais. Amazônia.

\section{THE HUNTERS OF THE RIOZINHO DO ANFRÍSIO: KNOWLEDGE AND CULTURAL PRACTICES BETWEEN NARRATIVES AND IMAGES}

\section{ABSTRACT}

This article illustrates the traditional knowledges and the cultural practices associated to hunting activity developed by the riverine population of the Riozinho do Anfrisio Extractive Reserve in Altamira municipality, in the state of Pará. The text is developed according to an ethnographic perspective and uses methods such us open interviews and participant observation. In the observed context, hunting constitutes one of the main productive activities of the social agents and presents itself as being permeated by symbolic elements. Curupira, Mapinguari and Matinta Pereira are examples of the superhuman entities that operate to regulate the action of the hunters. The hunted animals are utilised in many ways, in that they function as food as well as being employed in the preparation of remedies and in practices of magic.

\section{KEYWORDS}

Biodiversity conservation. Cosmology. Traditional Peoples and Communities. Amazonia.

1 Doutor em Biologia da Conservação pela Universidade de Lisboa, Portugal (2011), Professor e Pesquisador da Universidade Federal do Pará, com atuação nos Programas de Pós-Graduação em Antropologia (IFCH) e Agriculturas Amazônicas (NCADR). Bolsista de Produtividade em Pesquisa do CNPq (Nível 2). 
Ao mestre e amigo Valadar ${ }^{2}$, in memorian.

\section{Prelúdio: a primeira caçada}

0 tema da caça sempre foi instigante para mim porque eu não sei se é mais apaixonante estar entre os caçadores, aprendendo sobre esse universo que envolve aventuras fantásticas e segredos no interior da floresta ou por que na verdade gostaria mesmo era de ser o caçador. Certo é que, após inserir-me num terreiro de candomblé para acompanhar trabalho de campo de um orientando do Mestrado em Antropologia da UFPA, "descobri", via sacerdotisa da casa, que eu era filho de Oxóssi, orixá das caças, das matas e das farturas. Ela, antes de me conhecer e jogar os búzios, nunca soube de minha afeição por estes assuntos. Essa "descoberta",

\footnotetext{
2 Agradeço aos caçadores do Riozinho do Anfrísio, por permitirem experiências inesquecíveis, e às famílias que me acolheram em suas casas. Presto aqui uma homenagem especial (in memorian) ao Seu Valadar, caçador dos bons, que compartilhou comigo momentos inesquecíveis de aprendizagens. Seu Valadar era um caçador invejável, amigo querido e conhecedor profícuo das profundezas do Riozinho do Anfrísio. Recebeu-me pela primeira vez em sua casa com um jantar maravilhoso feito de porcão do mato assado na brasa acompanhado de farinha. 0 porcão tinha sido caçado por ele mesmo. Na altura da pesquisa já estava cansado por conta da idade e da doença que lhe acometia.
}

de alguma maneira, mexeu um pouco comigo, pois jamais tinha imaginado ser um "filho da mata".

Há décadas o assunto da caça vem despertando o interesse de pesquisadores (inclusive eu!) oriundos de diferentes disciplinas das ciências sociais e humanas, agrárias e naturais (ver, por exemplo, BONAUDO [et al], 2004; DESCOLA, 2006; VIVEIROS DE CASTRO, 1992; GARCIA, 2012; ANTUNES [et al], 2016), bem como diversificadas abordagens têm sido empreendidas nos estudos, sobretudo a caça como um problema ou ameaça à conservação da biodiversidade (PERES, 2001).

Neste texto pretendo trazer uma contribuiçãoao debate a partir de uma perspectiva etnográfica, valorizando a caça enquanto prática social e não apenas uma atividade humana cuja finalidade seja a obtenção de alimentos; aliás, pelo que tenho percebido nas mais diversas e longínquas regiões da Amazônia é que o papel da caça transcende a finalidade exclusiva de obtenção de proteína (BARROS [et al], 2012).

Proponho socializar saberes, tramas e narrativas a partir de 
experiências de campo vivenciadas com os beiradeiros ${ }^{3}$ da Reserva Extrativista (RESEX) Riozinho do Anfrísio, unidade de conservação de uso sustentável situada em um território conhecido como Terra do Meio, em Altamira, Pará. Extraí os apontamentos de antigos diários de campo; são, portanto, fragmentos de memórias. As anotações foram realizadas entre 2008 e 2010 e, até o presente, não tinham sido revisitadas. Tarefa que executo agora.

O subtítulo escolhido para alinhavar o fio condutor da escrita, "a primeira caçada", é proposital porque marca minha iniciação com o povo da Terra do Meio em termos de uma excursão de caça. No verão amazônico de 2008, após levar cerca de 10 dias viajando num barco pô, pô, pô, - como dizem na região sobre as embarcações de madeira que funcionam a motor -, finalmente, após termos navegado pelas águas selvagens do Rio Xingu, chegamos ao destino. Esta expedição ocorreu

3 Neste texto utilizarei sempre o termo beiradeiro para designar os interlocutores com os quais convivi, pois é assim que se autoidentificam. 0 termo ribeirinho, apesar de ser amplamente difundido, aqui não caberia, por ser, segundo os moradores, uma invenção do pessoal da cidade, da universidade, do governo. na companhia de duas professoras que, pela primeira vez, assim como eu, viajavam rumo ao Riozinho do Anfrísio, além do piloto e um pesquisador do Instituto Socioambiental (ISA).

A primeira colocação ${ }^{4}$ que conheci foi o Morro Verde, onde fiquei hospedado e tive a oportunidade de conhecer Zé Murraça e Dinaldo, filho e genro, respectivamente, dos donos da casa, Chico Preto e Dona Madalena. Nesta primeira viagem, minha intenção era conhecer o território, conversar in loco com as pessoas, fazer uma espécie de surwey inicial para dar prosseguimento às tratativas de autorização de pesquisa. Por esta razão, me detive a permanecer apenas no Morro Verde e depois Praia do Anfrísio, colocações localizadas no início da RESEX, na região conhecida como Baixo Riozinho.

No segundo dia após a chegada, já tendo demonstrado minha simpatia pela atividade de caça, Zé Murraça e Dinaldo convidaram-me a atravessar o rio e arriscar uma caçada. Fomos embora. Eles muito rapidamente,

4 Termo designado desde a época da exploração da borracha para delimitar o território/espaço de cada seringueiro. 
cada um com sua espingarda a tira colo e uma faca, logo chegaram à outra margem e iniciamos uma caminhada pelo interior da mata em busca de um "bicho de pelo" Sob o calor úmido do coração da floresta, e após menos de uma hora de andança em busca de uma presa, logo os caçadores contumazes daquele pedaço da Amazônia repleto de árvores gigantes e conservadas, anunciaram que uma vara de caititu (Pecari tajacu) se aproximava. Zé Murraça me pedira para ficar parado e não fazer barulho. Perguntaram-me baixinho se estava sentindo o cheiro do caititu ou se ouvia as pisadas do grupo se deslocando pelo chão da mata. Para ambas as indagações, respondi, não. Percebi de imediato o quanto minhas capacidades olfativas e auditivas eram insuficientes e alheias àquela situação. Ouvido e nariz imprestáveis para perceber os sons e cheiros da floresta. Mas o tiro do abate, único e certeiro, este sim, consegui ouvir claramente, o que me parece bastante óbvio. Foi quando um dos homens disse a alguns metros dali de onde eu estava parado feito um pau: Flávio! Pode vir. Com apenas um disparo, Referência local para os mamíferos.
Zé Murraça abateu o caititu que serviria para o almoço naquele dia.

Envolvido por aquela cena impressionante e fascinante, tudo me surpreendia. Meus olhos não desviavam dos rapazes um só minuto, nem meus ouvidos naquele momento vacilaram. Estava atento a tudo. A recomendação de ver e ouvir (CARDOSO DE OLIVEIRA, 2000) não me deixava falhar. Como, de maneira tão célere, encontraram aquele bicho? Que elementos, além da capacidade de perceber cheiros e pisadas, se tornam cruciais para facilitar o encontro fatal? E Zé Murraça completou: "às vezes eu consigo matar dois com apenas um tiro. 0 cartucho passa por um e vara no outro, e a gente mata dois".

Caititu morto, sangue a se derramar pelo chão. Primeiro abriram o bucho da presa, depois tiraram o fato, como se fala na região para se referir às vísceras, e partiram a cabeça. Tais técnicas objetivam deixar a peça menos pesada para carregá-la até a casa. Numa vista de olhos rápida pelo entorno da "cena do abate", a qual congregava caça e caçadores, logo os homens encontraram uma árvore para a extração da casca que 
imediatamente se transformaria num tipo de cordão forte, a envira, para fazer uma bem estruturada amarração em formato de mochila para transportar o caititu semilimpo (Figura 1).

Contrariando os conselhos de Foote White (1980), sobre manter um quase silêncio no princípio de um trabalho de campo em terreno novo, fiz algumas perguntas, e, noutras situações, eles próprios, os interlocutores, como "professores de caça", me explicaram coisas. Por exemplo, me ensinaram que para a retirada do fato, o corte tem que ser exato, para não furar o animal em lugar impróprio, o que causaria hemorragia, tornando mais inconveniente o traslado da presa.

Com tudo pronto, retornamos à residência e ao chegarmos notei que era do homem o papel de fazer a limpeza final da caça: retirar a pele, recolher algumas vísceras, as quais servem para alimentar os cachorros, geralmente muito magros, pois cachorros gordos não são bem sucedidos na caça. Em seguida, a caça passa a ser manipulada por mãos femininas, pois são as mulheres que vão preparar a carne, em diferentes versões: assada, cozida, moqueada. Infelizmente, após esta rica e inesquecível experiência, dentro de três dias tive que regressar a Altamira, pois deveria adquirir uma carona num barco do IBAMA que estava regressando de uma expedição com pesquisadores de diversas áreas, os quais desenvolviam na época estudos sobre diferentes aspectos da Terra do Meio.

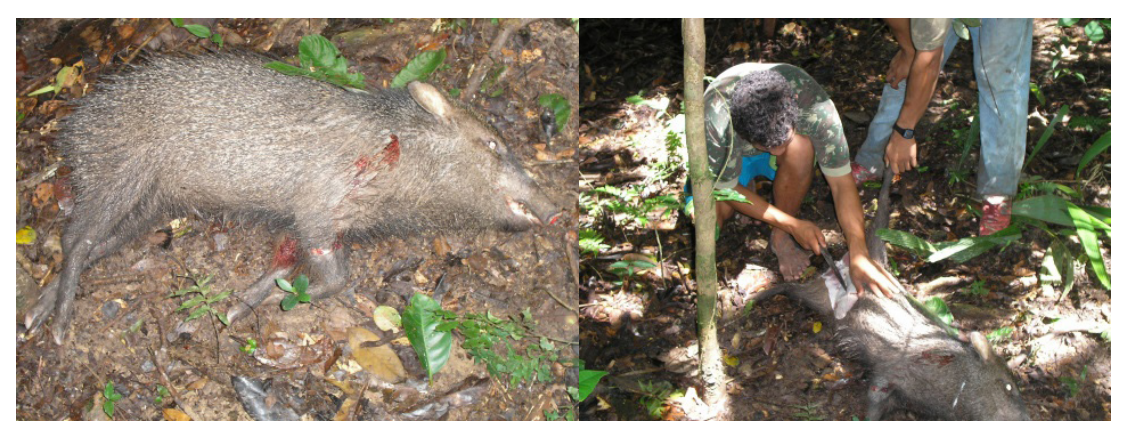



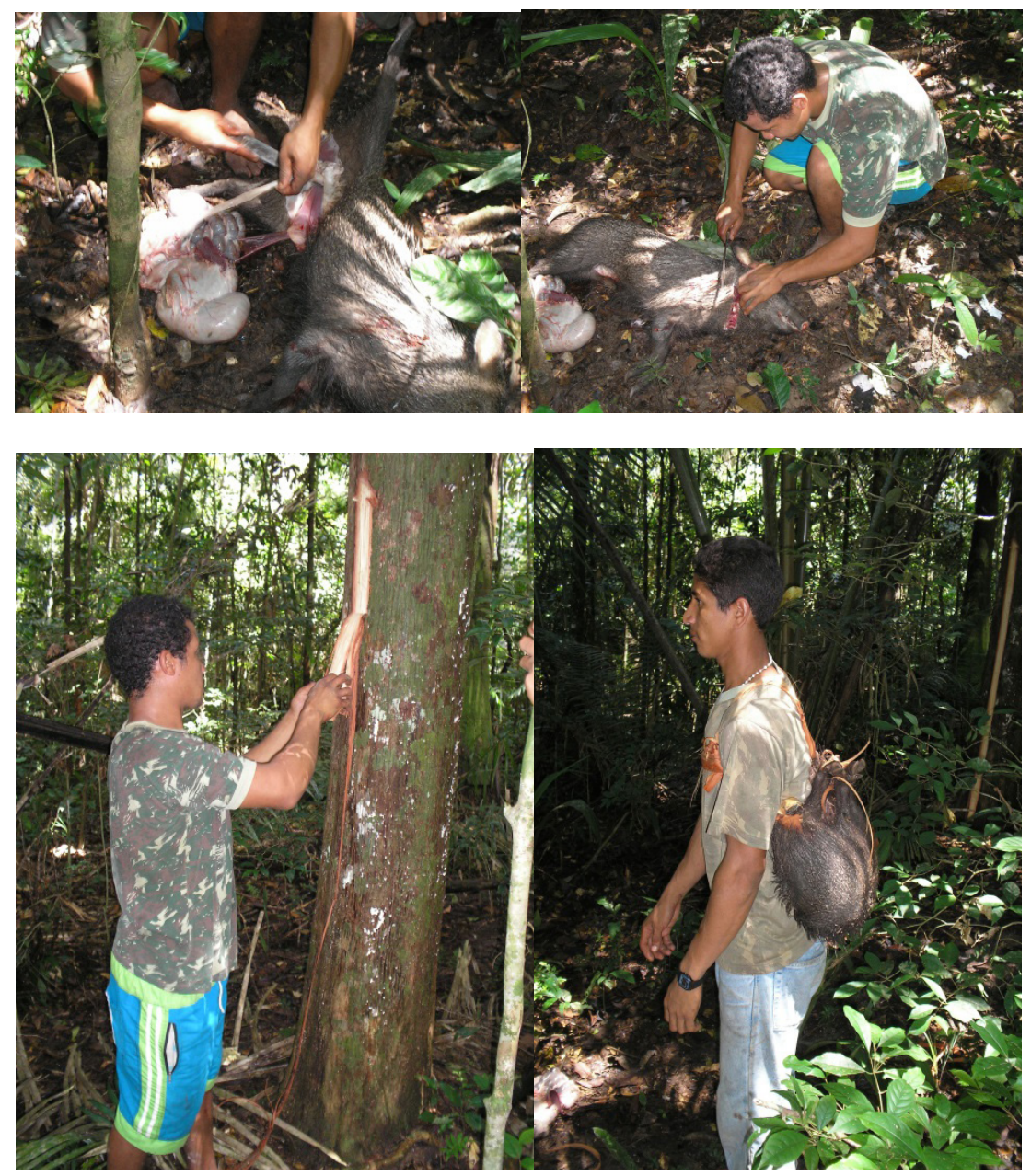

Figura 1: Sequência da caçada de um caititu. De cima para baixo e da esquerda para a direita. a) animal é abatido com apenas um tiro; b: abertura da parte ventral posterior (barriga) para retirada do "fato"; c: completa retirada do "fato"; d: corta-se a cabeça do animal para diminuir o peso durante o traslado até a residência; e: extrai-se uma parte da casca da árvore (envira) para amarrar o animal em formato de uma "mochila" para ser transportado; f: caça completamente amarrada e pronta para ser carregada. Colocação:

Morro Verde. Caçadores: Zé Murraça (esquerda) e Dinaldo (direita). Fotos: Flávio Barros (2008).

Riozinho do Anfrísio: contextos deve ao fato de a maior porção de de um território conturbado

O Riozinho do Anfrísio localiza-se na Bacia do Rio Xingu, em Altamira, no Pará, num território conhecido como Terra do Meio (TdM). Esta denominação se terras estar localizada entre dois grandes rios amazônicos, o Xingu e o Tapajós, mas tal denominação é uma externalidade, não tendo sido originariamente cunhada pelos nativos. 
A TdM constitui um mosaico de unidades de conservação federais e estaduais, com florestas nacionais, parques nacionais, estações ecológicas, reservas extrativistas e áreas de proteção ambiental, além das terras indígenas, pois a área abriga povos de diversas etnias (Xipaya, Arara, Araweté, Parakanã, dentre outros).

o nome Anfrísio é uma homenagem a um importante seringalista, Anfrísio Nunes, que dominou a região na primeira metade do século XX. No passado o Riozinho do Anfrísio foi palco de grande produção de borracha, quando migrantes nordestinos e de outras regiões da Amazônia se deslocaram para a região em busca de trabalho na atividade gomífera. Trata-se de território de grandes formações de floresta conservada, com espécies de alto interesse econômico, como madeiras nobres, seringueira (Hevea brasiliensis), Castanhado-Pará (Bertholletia excelsa), andiroba (Carapa guianensis), copaíba (Copaifera langsdorffii), dentre outras, além da presença de ouro e outros recursos naturais que despertaram interesse de exploradores, como grileiros, madeireiros e garimpeiros.

Em face desse cenário, no final dos anos 1990 e início dos anos 2000 , as famílias locais passaram a enfrentar a invasão de malfeitores, sobretudo exploradores de madeira e grileiros, cujo principal alvo era a apropriação ilegal da terra. Nessa época, as famílias de beiradeiros sofreram com ameaças, proibições de acesso aos castanhais e lagos sagrados de onde tiravam seu sustento. $\mathrm{Na}$ altura, viam-se placas espalhadas em vários locais, com frases do tipo "NÃO ENTRE, VAI MORRER!", "PROÍBIDO ACESSO", "ÁREA PRIVADA, PROÍBIDA A ENTRADA", colocadas pelos pistoleiros $\mathrm{e}$ agentes enviados por homens de dinheiro e que andavam a fazer pressão. Várias famílias, tomadas pelo medo, chegaram a vender suas colocações, sob a justificativa apresentada de não serem donas da terra.

Frente aos conflitos que se acirravam à medida que o tempo passava, as famílias se mobilizaram para lutar e, em parceria com movimentos sociais e instituições da região da Transamazônica e Xingu e de fora, montaram ação estratégica com o intuito de pôr fim 
aos abusos dos atores indesejados. Em 2005, após reivindicação da maioria dos moradores, o Governo Federal instituiu a Reserva Extrativista Riozinho do Anfrísio (Decreto presidencial no 215, de 9 de novembro de 2005); e montou uma missão gigantesca para se deslocar à região com a finalidade de marcar a presença do Estado e "dar segurança" aos beiradeiros que ainda recebiam ameaças de morte. A RESEX possui uma extensão territorial de 736.340 ha

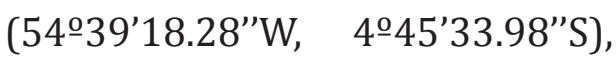
distando cerca de $400 \mathrm{~km}$ da parte urbana de Altamira.

0 povo do Riozinho do Anfrísio viveu durante muito tempo esquecido pelo Estado brasileiro. Aproximadamente, 95\% da população não dispunha de documentos básicos, como registro de nascimento, carteira de identidade e CPF. Não acessavam nenhum tipo de política pública, nem tampouco não havia escolas e nem postos de saúde até alguns anos. Somente após a criação da RESEX, órgãos do governo passaram a desenvolver diversas ações na área, como emissão de documentação, implantação de escolas (a partir de 2008), contratação de agentes comunitários de saúde, mutirões com atendimento médicoodontológico, bolsa família, auxílio maternidade, dentre outros.

0 deslocamento até essa região se dá por via fluvial, saindo de Altamira de barco ou voadeira (uma espécie de lancha rápida), o que pode levar de alguns ou muitos dias a depender da época do ano (no inverno a viagem é bem mais rápida!), ou via terrestre/ fluvial, pegando a rodovia Transamazônica até a Trans-Iriri, chegando ao Porto da Maribel, de onde se deve continuar a viagem pelo rio. Existe ainda opção de chegada por avião fretado, pois há uma pista instalada na colocação Praia do Frisan, a qual esporadicamente é utilizada com esta finalidade.

As principais atividades produtivas das famílias são o extrativismo de Castanhado-Pará e de óleos vegetais (copaíba, andiroba), a pesca, a confecção de farinha de mandioca (principalmente para o consumo) e o cultivo de produtos vegetais nas roças. Além disso, coletam vários frutos da floresta ou das roças/quintais para o consumo, 
tais como açaí, cupuaçu, patauá, biribá, cajá, bananas de diversos tipos etc. A criação de pequenos animais, como patos e galinhas, e a caça, encerram o conjunto de atividades produtivas. Todas essas práticas são realizadas pelos diversos membros das famílias e respeitam um calendário ecológico, dividido em inverno (dezembro a maio) e verão (junho a novembro). Por exemplo, a coleta da castanha acontece no período do inverno, entre janeiro e março, quando geralmente os homens, acompanhados de suas esposas e filhos, se deslocam para os castanhais e lá permanecem acampados por diversos dias ou semanas. As casas enfeitam a paisagem do Riozinho. Elas são construídas com matéria-prima oriunda da biodiversidade local, como fibras vegetais e madeiras (Figura 2).

0 sistema econômico do passado era o escambo, que consistia da troca de produtos do extrativismo dos beiradeiros por mercadorias "vendidas" pelos regatões em suas embarcações que funcionavam como um mercado itinerante, sendo o sabão, biscoitos, isqueiro, óleo de cozinhar, café, açúcar, pilhas, algumas das mercadorias adquiridas pelos moradores. Hoje, mesmo com o acesso às políticas do Estado pelos comunitários, este sistema ainda perdura, em face da distância e complexidade geográfica do lugar em relação ao maior centro urbano da região, Altamira. Contudo, atualmente algumas famílias viajam esporadicamente para Altamira com o intento de receber seus proventos e adquirir mercadorias a preços mais razoáveis. Lembro que em 2009, quando estive acampado no Igarapé do Limão, área de castanhais, vi alguns beiradeiros "comprarem" caixas de chocolate da marca garoto por cerca de $\mathrm{R} \$ 20,00$ (vinte reais)/unidade, quando em Belém custava $\mathrm{R} \$$ 3,99 (três reais e noventa e nove centavos). A moeda de troca era a castanha.

Atualmente há cerca de 70 famílias residindo na área e muita coisa mudou desde a época em que o território se transformou em reserva, há 10 anos. Há escolas mantidas pela Prefeitura de Altamira, boa parte das famílias dispõe de motor rabeta e geradores que funcionam 
a gasolina ou óleo diesel. Por outro lado, alguns costumes estão sendo abandonados em razão do maior contato com a cultura urbana da cidade. Por exemplo, a medicina tradicional, que no passado era mais valorizada, hoje está sendo substituída pelo tratamento via medicina moderna. Houve famílias que se deslocaram para a cidade em busca de estudos para os filhos, ou empregos em fazendas e lotes, no caso dos homens e jovens. Há notícias de que a internet também já chegou ao Riozinho.

Ainda que muita coisa tenha avançado, as pressões pela madeira e o ouro existentes no território ainda persistem, gerando conflitos entre moradores, lideranças locais e agentes indesejados, dificultando o alcance dos objetivos para os quais a reserva foi criada: a proteção dos recursos naturais e das comunidades tradicionais e seus modos de vida. Soma-se a isso as dificuldades enfrentadas pelo órgão gestor, o ICMBio, que dispõe de apenas um chefe e parcos recursos financeiros para conduzir uma boa gestão. Com efeito, vez ou outra se ouve notícias do tipo "a cabeça de fulano tá custando x", como ocorreu com seu Raimundo Belmiro, expresidente da AMORA (Associação dos Moradores do Riozinho do Anfrísio), que permanece até hoje sob a proteção da Secretaria de Direitos Humanos da Presidência da República. As juras de morte se deveram em razão das constantes denúncias que fez sobre os invasores que visam explorar os recursos florestais e o ouro.

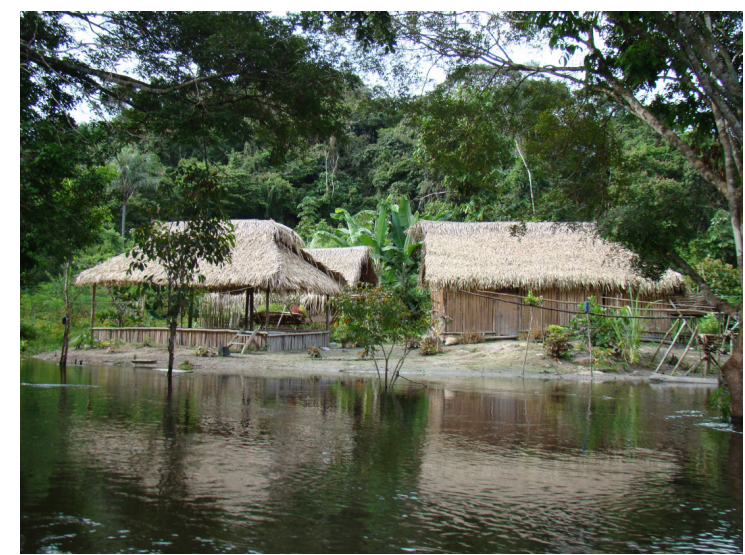

Figura 2: Casa, rio, floresta e roça: elementos da paisagem. Tempo de inverno no Riozinho. Foto: Flávio Barros. 
Como realizei o estudo?

0 empreendimento foi conduzido entre 2008 e 2010. Neste período efetivei oito excursões ao Riozinho do Anfrísio, com períodos de permanência que variavam entre 15 e 40 dias. As autorizações foram concedidas pelo órgão gestor da unidade de conservação (ICMBio) e também pela comunidade. Para esse procedimento "ético" tive que redigir um termo de anuência prévia (TAP), o qual foi lido em reunião do conselho deliberativo da RESEX e aprovado, e depois assinado pelos presentes.

Em razão da distância e do alto custo financeiro para conduzir pesquisa no território em comento, precisei contar com o apoio do ICMBio em diversas viagens de campo, além da própria UFPA. Uma vez estando no Riozinho, recebi auxílio das famílias e dos jovens, que me ajudavam a se deslocar de um lado pra outro de canoa ou mesmo de barco, quando alguém possuía este último. $\mathrm{Na}$ altura existiam aproximadamente 55 famílias e todas foram visitadas. Entretanto, selecionei cerca de 10 famílias que serviram de base de apoio e daí me deslocava para as várias colocações nas três regiões do Riozinho: baixo, médio e alto Riozinho.

As viagens eram sempre bem complexas, pois exigiam mãode-obra medonha, sendo preciso organizar barris de combustível, compra de rancho, aluguel de voadeira; além de ordenar todo material de campo e pessoal, pois esquecimento e erro são dois fatores que não são muito bem vindos quando se trabalha nos confins da Amazônia.

De modo geral, comíamos tudo o que a floresta e o rio nos ofereciam. As roças, ricas de plantas alimentícias, nos ofertavam abóbora, macaxeira, frutas, farinha. Dos rios vinham os peixes - meus preferidos eram pacu, tucunaré e pescada branca. Da mata, os comunitários sempre arranjavam um bicho de pelo ou de pena para as refeições. Queixada (porcão do mato) e veado mateiro eram minhas carnes prediletas. Como levava arroz, feijão, temperos e outras comidas "raras" para eles, a gente sempre compartilhava as refeições. 0 banho era no rio e a dormida sempre em rede com mosquiteiro por causa dos mosquitos perversos. 
Em termos metodológicos, a observação participante (MALINOWSKI, 1978) foi essencial para entender minimamente o modo de vida do povo do Riozinho. De fato, conviver com as famílias, ir à caça, à pesca, participar das festas, das brincadeiras, jantar com eles, se envolver nas tramas, participar da feitura da farinha e até realizar minhas necessidades fisiológicas no mato, foram cruciais para o meu processo de formação no território. De fato estar lá (GEERTZ, 1997) foi um exercício fulcral de aprendizagem.

Conduzi tanto entrevistas estruturadas

como semiestruturadas (HUNTINGTON, 2000) e o registro fotográfico a partir dos princípios norteadores da Antropologia Visual foi essencial para se complementar ao texto etnográfico (ECKERT; ROCHA, 2008). Neste sentido, a fotografia ganhou significado não apenas como um registro visual, mas como uma forma de traduzir imageticamente o universo da caça no contexto estudado.

Para compreender os diversos processos que se vinculam à atividade da caça no Riozinho do Anfrísio, escolhi a Etnoecologia, uma disciplina híbrida e de natureza interdisciplinar (PRADO; MURRIETA, 2015), que coloca em contato as ciências sociais e as ciências naturais. 0 termo Etnoecologia foi empregado pela primeira vez em 1954 por Harold Conklin (1954), em seus estudos sobre agricultura com os Hanunoo, nas Filipinas. Toledo e Alarcón-Cháires (2012), nesse sentido, defendem a Etnoecologia como uma disciplina de fronteira ou emergente, não apenas por sua conexão entre campos distintos da ciência, mas por considerar que seu marco teórico-conceitual está em processo de construção, mesmo após passadas seis décadas. No âmbito dos saberes enquanto campo de estudo, optei por seguir as abordagens pontuadas tanto por Santos [et al] (2005), o qual problematiza a noção de ecologia de saberes, como por Geertz (1997).

\section{Caça como campo de investigação: apontamentos e reflexões}

Como dito anteriormente, o tema da caça tem suscitado o interesse de estudiosos de diferentes áreas do conhecimento, mas é no campo das ciências naturais que o assunto se 
sobressai. Os estudos nessa área, na maioria dos casos, se debruçam a entender o impacto (negativo!) das populações humanas sobre os recursos cinegéticos, uma vez que a atividade é proibida por lei no Brasil (Lei no 9.605/1998), muito embora haja certa flexibilidade para as comunidades indígenas e povos tradicionais que caçam com finalidade de saciar a fome. O rigor da proibição se torna mais acentuado quando se trata de unidades de conservação, cujos gestores, na maioria dos casos, defendem a perspectiva do preservacionismo exacerbado. Prevalece aí a defesa de que a natureza só vai bem se estiver intocada (DIEGUES, 2004). A fragilidade desses estudos se assenta na ideia homogênea e unilateral de que todas as sociedades que caçam o fazem de forma destrutiva.

É no campo da Antropologia, ou das disciplinas híbridas, como a Etnoecologia (TOLEDO; BARRERA-BASSOLS, 2009) que os elementos socioculturais da caça, enquanto atividade humana, são mobilizados descortinando a riqueza de saberes, práticas, lógicas e sociabilidades que a norteiam. Não quero aqui defender a tese de que toda atividade de caça, em qualquer contexto, envolvendo povos e comunidades tradicionais, seja sustentável. Longe disso, defendo a ideia de que cada caso é um caso e, portanto, deve ser tratado com rigor. E neste texto irei valorizar a perspectiva antropológica.

Várias investigações ao redor do mundo contribuíram para uma compreensão abrangente da caça como uma das práticas mais importantes desempenhadas pelas sociedades humanas que vivem em contextos rurais. Service (1971), ao estudar os índios canadenses, trouxe notáveis contribuições para o entendimento do papel da caça na vida dos algonquianos e atabasquianos, que caçavam caribu e boi almiscarado na tundra e veados, búfalos, castores e coelhos, na parte de floresta. Em seu artigo intitulado "Percepções da presa: caça, sedução e metamorfose entre os Yukaghirs da Sibéria”, publicado no Anuário Antropológico, Willerslev (2011) trouxe a perspectiva da caça como um ato não apenas de predação, mas de "fazer amor", pois, como diz este autor: 
A questão do fazer amor talvez fique mais claramente enfatizada pelo fato de os Yukaghirs verem a caça como um processo de "sedução sexual": o caçador objetiva seduzir sexualmente o animal, para este "entregar-se" a ele, do mesmo modo que ele se arrisca a ser seduzido pelo espírito do animal (WILLERSLEV, 2011).

Em sua etnografia, também fica evidente a condição de fluxo que permeia a vida dessa sociedade, uma vez que o líder do grupo de caçadores pode ser substituído por outro caso cometa injustiça na hora de repartir a carne obtida em partes iguais. Da mesma forma, esta condição encontra-se presente em outros tipos de seres vivos habitantes da floresta, pois humanos podem se transformar em animais, animais em humanos e os mortos convertem-se nos vivos. Portanto, como comenta Willerslev (2011), não existem fronteiras fixas, apenas uma interminável continuidade de transformações.

Já em território amazônico, a teoria do perspectivismo ameríndio, desenvolvida por Viveiros de Castro (1992, 1996), marca o início de uma nova forma de pensar a relação natureza e cultura a partir de sua etnografia conduzida entre os Araweté, povo caçador do Xingu. De acordo com sua tese, a dimensão que interliga humanoseanimaiséahumanidade, portanto, todos os seres seriam dotados de uma cultura. A noção de "roupas" presente em seu pensamento serviu para explicar que os animais da floresta, na cosmologia Araweté, são parentes que morreram e retornaram ao plano terreno disfarçados de paca, veado, queixada, pois é assim que aparecem aos olhos dos humanos; vê-los dessa forma trata-se de uma questão de perspectiva. Fugindo de uma visão cartesiana das dimensões natureza e cultura, aclamada pela ciência ocidental, o autor defende a ideia da inversão, apostando na universalidade dos espíritos, portanto, da cultura, do sujeito; e uma particularidade dos corpos, dos objetos, ou seja, da natureza, enfatizando que a dissociação dos domínios natureza e cultura é insustentável para a compreensão das cosmologias ameríndias. Neste caso teríamos um multiculturalismo universal e um multinaturalismo particular.

Distintamente do dualismo moderno, que divide os humanos e não-humanos em domínios 
ontológicos mais ou menos estanques, as cosmologias amazônicas apenas fazem uma diferenciação de grau, não de natureza (DESCOLA, 1998; 2006). Para os Achuar, na Amazônia equatoriana, tanto os animais como as plantas possuem alma (wakan) similar a dos humanos. Em "As lanças do crepúsculo", Descola (2006) narra vários episódios capturados entre os Achuar, que demonstram a ausência de fronteira entre os domínios natureza e cultura, como por exemplo, no caso das roças Achuar, em que as plantas são cuidadas como filhos, pois a mandioca é dotada de wakan.

\section{Caçar o quê? Quando?}

A caça no contexto do Riozinho do Anfrísio apresenta múltiplas finalidades, sendo a alimentar a mais importante delas (Figura 3). Os beiradeiros geralmente costumam aproveitar ao máximo o animal abatido. Após a captura, todas as partes úteis são recolhidas. Por exemplo, ao abater um veado mateiro, além de comer sua carne, os ossos das pernas podem ser armazenados para preparar remédio para crianças que apresentam dificuldade de andar, assim como seus chifres são utilizados como cabides. Observei em várias residências chifres de veado acoplados ao alto na cozinha para servir de suporte para pendurar um pano, uma sacola. De modo geral, a utilidade gira em torno da alimentação, remédio, utensílio doméstico e amuleto. Há uma diversidade imensa de animais úteis nessa região, presentes tanto em ecossistema de terra firme, como nos rios e igarapés. Listei mais de 50 tipos, sem contar os peixes. Os mais emblemáticos são a capivara, veado mateiro, porcão do mato, caititu, paca, cutia, anta, vários tipos de tatus. No domínio aquático são apreciados o jacaré e a tracajá, além dos jabutis amarelo e vermelho, que são encontrados geralmente no chão da floresta.

Esse recurso é abundante o ano inteiro, havendo épocas em que determinadas espécies podem estar mais escassas ou não, a depender de fatores como reprodução, frutificação, estação do ano. Apesar de a caça ser farta praticamente todo o ano, existem regras locais quanto a datas e épocas em que se pode ou não caçar. 


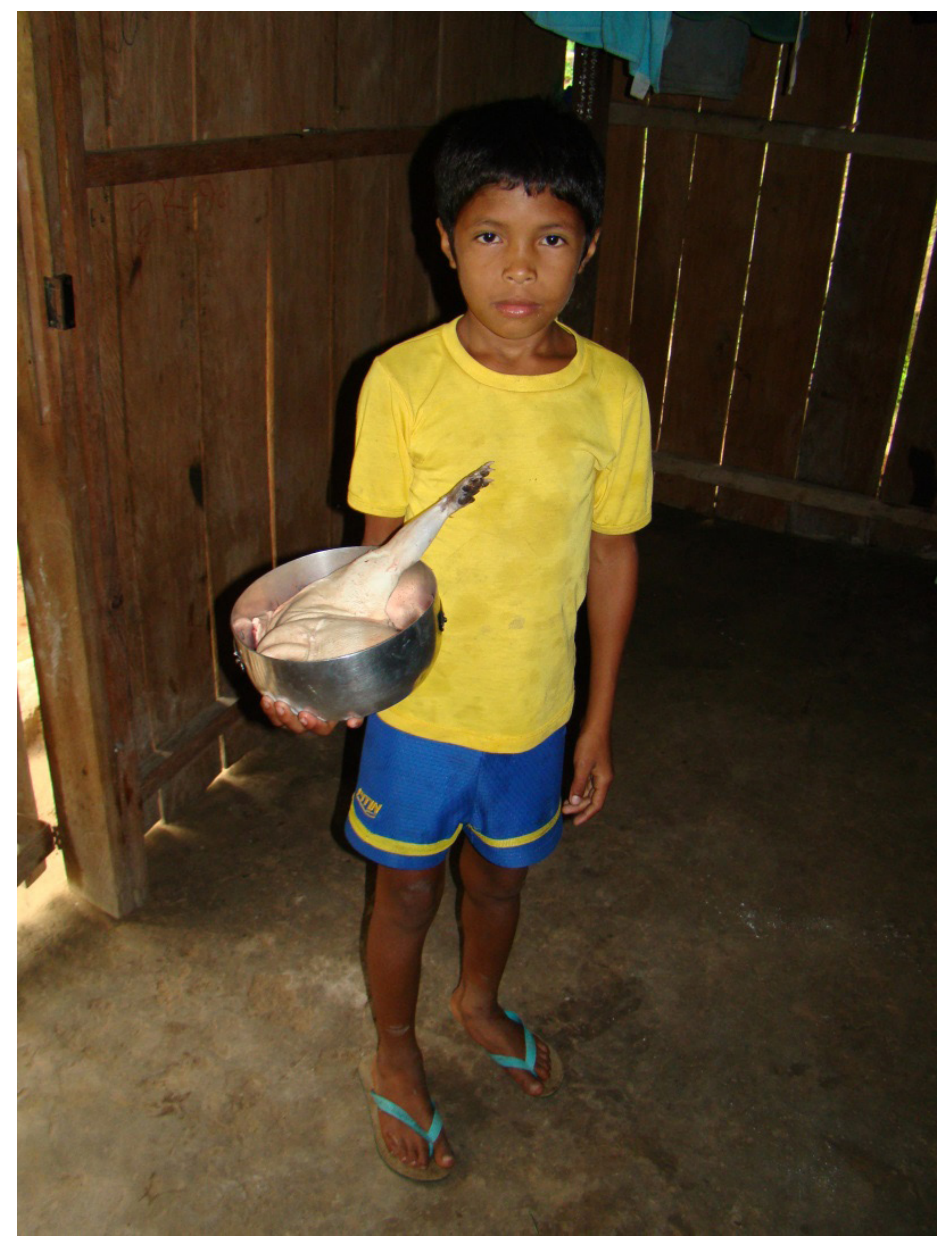

Figura 3: Menino levando um pedaço de paca para presentear a vizinha. Foto: Flávio Barros

Neste contexto, há um Nestes dias não se pode caçar, conjunto de datas importantes que nem realizar outras tarefas como pode estar conectado a um santo ou a um acontecimento, trazendo certos interditos à prática da caça e de outras atividades. Dezenove de março, dia de São José; 25 de dezembro, Natal; semana santa; 24 de agosto, data em que "houve o primeiro crime no Brasil" 6 .

6 Quando perguntei que crime foi e como pescar ou ir à roça. Na cosmovisão local essas datas são sagradas ou devem ser guardadas com cuidado,

ocorreu, eles contaram esta história: foi aquele crime em que o irmão matou o próprio irmão. Percebi que a narrativa tinha conexão com a passagem bíblica que se refere a Caim e Abel. Para os beiradeiros, neste dia o "diabo anda solto", portanto, não se pode executar nenhum tipo de trabalho no rio, na roça ou na mata. 
portanto, devem ser respeitadas. E quem se sujeita a transgredir a regra, pode se prejudicar. Com efeito, ouvi relatos de caçadores que se perderam, como Bode, filho de Dona Dora e Seu Domingos, que ficou pelejando vários dias na mata sem encontrar o caminho de casa porque foi caçar no dia de Natal, desobedecendo a seu pai que havia feito recomendação contrária.

Uma cena que ficou marcada em minha memória foi o episódio da mucura. Num certo dia, durante trabalho de campo na colocação Bom Jardim, durante a semana santa de 2009, quando estávamos almoçando, os cachorros da casa começaram a latir no terreiro. Continuamos a almoçar, mas o filho mais velho foi averiguar o que se sucedia. Dadinho, então, chamou os seus dois irmãos, Edileno e Herculaninho, para pegar o bicho que o cachorro tinha encurralado num buraco. Ao cavar o terreno com a enxada, perceberam que se tratava de uma mucura (Didelphis marsupialis) com filhotes em seu marsúpio. Como em geral esse animal, quando visto, é morto pelos moradores, pois é predador voraz de galinhas, pintos e ovos, nessa situação, Dadinho retrucou: "Tira o cachorro daí. É uma mucura e tá com filho. Vamos tirar ela e jogar no mato. Não pode matar ela porque é semana santa (Dadinho, morador da RESEX)".

Vê-se na atitude dos sujeitos um compromisso em cumprir a ordem cosmológica de não abater o animal pelo fato de ser semana santa, ainda que ele seja classificado como animal ofensivo.

As caçadas também são guiadas pelas fases da lua, sendo a lua cheia a época mais complicada para caçar a noite, por causa da claridade excessiva, o que faz com que os animais fiquem mais espertos e vejam o caçador.

0 verão me parece ser é a melhor época do ano para caçar e as justificativas são várias: a mata fica mais enxuta; com o calor dessa época, a caça costuma se concentrar com mais frequência nos barreiros e açaizais no interior da mata, locais que conseguem manter um estoque mínimo de água, fenômeno que acaba facilitando a identificação das presas pelos caçadores, uma vez que sabem localizar precisamente estes ambientes; com a escassez de água na floresta, os animais 
passam a visitar com maior frequência a beira do rio; há mais facilidade de ouvir os animais no interior da mata porque o solo fica seco. Já no inverno a mata fica mais escura, chove muito, a terra fica bastante molhada e o barulho da chuva dificulta encontrar a caça a partir de seus movimentos de deslocamento. As narrativas abaixo ilustram as razões:

0 verão é melhor de caça porque a mata é enxuta e limpa. Já no inverno é mais barulhento, tudo fica molhado (Mair, morador da RESEX).

No verão é melhor porque os porcos ficam próximos da beirada (Seu Pedro, morador da RESEX).

Apesar das justificativas e explicações, encontrei caçadores que preferiam caçar no inverno, pois nesta altura do ano existe maior disponibilidade de frutas para os bichos se alimentarem e por isso exploram uma diversidade maior de ambientes no interior da floresta. No dizer de um dos caçadores: "nessa época do ano a caça anda mais!" Quem optou por esta época também explicou que o chão da floresta fica mais úmido, tornando-se mais fácil identificar o rastro do animal. A seguir alguns relatos dos entrevistados: "O inverno é melhor porque dá pra ver o rastro do bicho. Já no verão eles não deixam rastros" (Sr. Valadr, morador da RESEX); "No inverno tem mais fruta para o bicho comer" (Seu Belmiro, morador da RESEX).

Curupira, Mãe da Mata, Mapinguari, Matinta Pereira: guardiães das caças - Sobre regras locais de conservação e acesso aos recursos cinegéticos

Diversas entidades sobrehumanas dominam a cena das caçadas no Riozinho do Anfrísio. As caças nunca estão sozinhas. Elas têm donos, as matas têm donos, tudo tem dono, até mesmo o rio, de acordo com os interlocutores. Entre os "sujeitos" protetores das matas e dos animais estão Curupira, Mapinguari, Mãe da mata, Matinta Pereira e Saci, os quais andam por todos os lados da floresta e têm como missão cuidar dos animais e perseguir e prejudicar quem caça de maneira descontrolada. Os entrevistados discorreram fatos vividos; ou que ouviram falar, de pessoas que se perderam na mata, ou levaram surra cujo agressor era invisível aos olhos humanos. Os caçadores descreveram acontecimentos horrendos que envolviam gritos de dor, incapacidade de fugir de quem 
os machucava, visagens, criaturas cobertas de fogo, o desejo de que os olhos pudessem ver o caminho de volta pra casa, mas sem sucesso. Alguns relatos são reveladores:

Já vi cachorro apanhando e rolando na folha sem ver ninguém. Acho que era Matinta Pereira. Já vi muita misura na mata, mas não tenho medo. Já vi balançarem árvores. Acredito que esse ser existe para castigar quem faz malvadeza, estragos (Seu Reginho, morador da RESEX).

Acho que deve existir a Mãe da mata e o Curupira. Já ouvi falar. Já vi gente receber castigo porque fez malvadeza com as caças (Dona Francineide, moradora da RESEX).

Descola (2006), nesse sentido, também verificou a presença de mãe da mata na cosmologia Achuar, denominada de Jurijri. Esse ser, descreve Descola (2006), usa botas, um capacete de ferro e uma espada. Na nuca, tem uma boca com dentes enormes, que a gente não vê por causa do cabelo. Com essa boca, ele come as pessoas que zombam da caça, matam os animais para nada, por prazer.

A esse despeito, no texto intitulado "O Curupira e os mitos de inversão", Fernandes (2014) discorre sobre a simbologia da troca entre o animal e o homem, se referindo ao Curupira. A autora pontua o seguinte:

Em todos os relatos apresentados repete-se a cena em que o Curupira persegue o caçador como se ele fosse a caça. Exatamente como animal caçado, o homem entra em pânico, perde a voz e se vê paralisado de terror. Como um animal abatido, ele é amarrado pelos pés e colocado de "cabeça para baixo". O caçador se torna a caça (FERNANDES, 2014).

Com efeito, é marcante a interpretação pontuada por Fernandes (2014), ao afirmar que se pode inferir que o Curupira parece ser uma criação do imaginário humano que busca cumprir as exigências paradoxais do próprio mundo selvagem: para compensar os excessos da ação predadora do homem sobre a natureza, e para regular as perdas que o homem provoca no mundo selvagem, o deus troca eventualmente os termos. Assim a imaginação humana parece reproduzir, através das histórias e dos símbolos, a própria lei primordial e misteriosa da natureza: atender à necessidade de equilíbrio entre vida e morte, perdas e ganhos, caça e caçador. Esta reflexão encontra conexão com os fatos ocorridos no território 
estudado. Seu Herculano, um dos moradores mais antigos, durante uma conversa, narrou a seguinte história:

Olhe, eu acho que existe alguém que cuida dos bichos na mata. Vou lhe contar uma história. Um belo dia eu tava no mato... escutei a zuada do veado andando pelo mato. Cheguei bem pertinho dele, uns 5 metros, dei o tiro, mas quando eu cheguei mais perto, vi que ele não tava mais lá. Eu tenho certeza que vi ele caído, pois só dei um tiro e acertei. Tinha dado ele como morto. Era um veado mateiro, eu até cheguei a ver ele caído no chão entre os galhos. Mas quando eu olhei, ele não tava mais. Conseguiu fugir? Não, alguém carregou ele, cuidou dele. Levaram ele pra algum lugar. Só sei que quando eu cacei outro veado mateiro, um ano depois, vi que era o mesmo veado que eu tinha acertado. Eu conheci por causa do cartucho que achei no bucho dele. Então quer dizer que ele foi tratado, carregaram ele para algum lugar, não é? (Seu Herculano, morador da RESEX).

O papel de cuidar do veado foi cumprido pelo Curupira, que deve tê-lo levado para um lugar recôndito na floresta, um lugar que ninguém conhece: pelo menos os humanos. Nas palavras desse renomado caçador, lá é como um hospital dos animais, onde as caças são tratadas quando os humanos as molestam.
De fato a crença nesses elementos reguladores da natureza é bem marcante nesse pedaço da Amazônia. Lembro-me de um evento interessante que vivenciei. A história envolveu seu Zé da Mata, um caçador dos seus cerca de 70 anos, morador da colocação Bom Jardim. Ele havia me informado sobre a intenção de sair para caçar um porco do mato porque estava com vontade de comer essa caça. Tão logo adentrou a mata, com pouco tempo de caminhada, encontrou uma "jabota" (a fêmea do jabuti) e disse para ela: "não era tu que eu queria, eu quero um porcão. Vou fazer um acordo contigo. Me mostra o porcão, eu te deixo amarrada e se encontrar o bicho, na volta te solto" (Seu Zé da Mata).

0 caçador, de regresso, explicou-me que amarrou a jabota como forma de garantir a carne, caso não tivesse achado o porco. Porém, como ela havia mostrado para ele um porcão, o velho caçador percorreu um caminho longo de volta para retornar ao local que tinha amarrado o réptil. 0 homem, então, libertou a jabota. Quando o indaguei sobre sua atitude, ética demais para mim, ele prontamente 
respondeu: "para que eu ia pegar a mais se o porcão dava pra todo mundo comer?" E completou: "E também ela me mostrou o porco. Eu tinha que cumprir o acordo que fiz porque podia me prejudicar".

Cumprir o acordo significa dizer que na sua visão, não se pode exagerar, caçar além do necessário. Por outro lado, o animal é dotado de agência, pois teve a capacidade de atender aos anseios do caçador na medida em que lhe mostrou a caça desejada, o porcão. Essa dimensão ética para com os animais de caça está presente em todo território. Amiúde registrei animais silvestres serem criados no ambiente doméstico e há várias razões para explicar a presença desses xerimbabos entre os humanos no espaço doméstico. Vejamos.

Quando um caçador abate, por lapso, uma fêmea grávida ou com filhote, instalam-se problemas para o culpado. 0 caçador pode ficar com panema ${ }^{7} \mathrm{e}$ tem que assumir o papel de levar o bacuri ${ }^{8}$ indefeso para o seio de

\footnotetext{
7 A panema é um estado de infortúnio que vez ou outra acomete algumas pessoas, trazendo má sorte às suas atividades de pesca, caça etc.

8 Termo usado para filhotes, geralmente dos "bichos de pêlo", os mamíferos.
}

sua família e criá-lo. Ao chegar a casa esse animal é acolhido com alegria por todos, principalmente pelas mulheres e crianças, que logo dispensam cuidados e afetos. Geralmente recebem um nome e passam a conviver no ambiente doméstico; em determinados casos, dentro de casa. Milo foi um jacamim que conheci na colocação Bom Jardim. Vivia entre as pessoas, era amistoso, adorava carinho e respondia quando imitávamos seu canto. Quando regressei ao campo e me alojei nesta família, Dona Vitorina, a matriarca, encontravase entristecida e mergulhada numa saudade tremenda porque um gato maracajá havia abatido $\mathrm{o}$ xerimbabo em cima da casa.

A criação de xerimbabos pelas pessoas não ocorre apenas em função da questão já mencionada, mas por outras motivações. Querem uma companhia diferente, ou os consideram bonitos e aí podem objetivamente ir à mata exclusivamente com este intento: buscar um animal silvestre para criar em casa. Veados, caititus, porcos do mato, antas, macacos, mutuns, jacamins, araras, papagaios, são exemplos de animais que frequentemente 
são vistos sendo criados entre os beiradeiros. Este costume é amplamente difundido entre as populações ameríndias, como destacou Erikson (2012) em seu estudo junto aos Matis. No artigo "Animais demais...os xerimbabos no espaço doméstico matis (Amazonas)", Erikson (2012) afirma o seguinte: concretamente, os animais estão em todos os lugares: nas malocas, nas roças, nos locais de banho e até sobre a cabeça das crianças; tal como ocorre no contexto aqui estudado. Como a Terra do Meio é habitada por povos indígenas, esse costume certamente se derivou das zonas de contato estabelecidas entre os índios e os beiradeiros desde a época da borracha, quando migrantes nordestinos foram chegando à área entre a segunda metade do século XIX e princípios do XX.

A postura ética dos beiradeiros pôde ser a mim explicada por meio de um questionamento feito por um dos interlocutores: se o seu filho ficasse sozinho, sem mãe, ele iria se criar? Da mesma forma os bichos da mata. Eles são iguais a gente; precisam de cuidado também (ver Figura 4). Intrigante é que na mata esses animais são a caça que deve ser comida, mas, à medida que são criados no ambiente doméstico, deixam de ser; pois são tratados como humanos, recebem nomes, são mimados, têm lugares para dormir e jamais são abatidos quando se tornam adultos. Por vezes desaparecem pela mata quando atingem a maturidade sexual, uma prova de que sua liberdade não é cerceada.

Uma regra básica de abate
Figura 4: Caçador dando leite a uma veadinha. Foto: Ângelo Lucena.

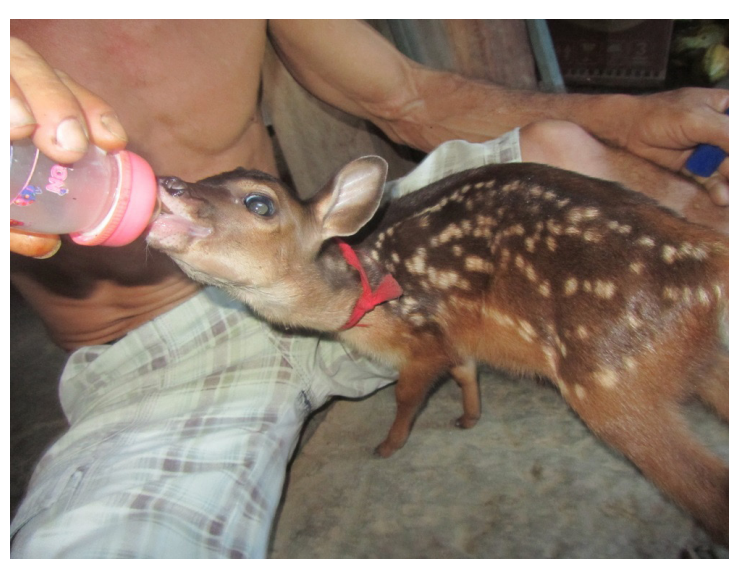


é quanto ao local permitido para caçar, o qual está restrito à colocação do morador. Pessoa externa à colocação só pode caçar se o dono da área autorizar ou convidar. Contudo, se uma caça aparecer durante viagens realizadas ao longo do rio, estando ou não no perímetro da colocação do viajante, este pode acessar a caça. Em áreas desabitadas ou de uso comum, qualquer pessoa pode caçar.

De modo generalizado os homens caçam somente o necessário para se alimentar, por considerarem o estrago uma conduta inadequada. Quando ocorre de caçarem além do que a família conseguiria consumir, geralmente parte da carne é salgada para que dure mais tempo. Um costume comum é a partilha da caça com os vizinhos, que ocorre tanto na situação de caçar apenas o suficiente para a família, como em caso de excedente.

Em relação ao critério para abater a caça, tamanho/idade é a melhor forma de selecionar as presas, mas o sexo também se constitui como um critério, além da presença de filhotes e fêmeas grávidas. Com efeito, isso não significa dizer que existe um padrão de atitudes, podendo haver caçadores que não sigam tais critérios.

\section{Como se caça no riozinho do Anfrísio?}

A caça é uma atividade eminentemente masculina, porém, em alguns casos, é possível encontrar mulheres que se arrisquem a pegar um bicho. No nosso contexto, duas mulheres informaram que caçam esporadicamente e em situações de necessidade. De modo geral a formação do caçador ocorre a partir das observações de como os pais e irmãos mais velhos procedem. As crianças, ainda pequenas, costumam assistir e/ou ajudar os pais a tratarem as caças nos terreiros de casa, quando os mesmos chegam do mato (Figura 5). Quando os filhos se tornam adolescentes começam a acompanhar os pais ou irmãos mais velhos diretamente na floresta para iniciarem o processo de aprendizagem, até que sejam autorizados pelos pais a darem os primeiros tiros. As principais técnicas empregadas na caça, são a espera, a excursão com cachorro, a excursão sem cachorro, as armadilhas, lanternagem e o que eu chamei de encontros ocasionais. 


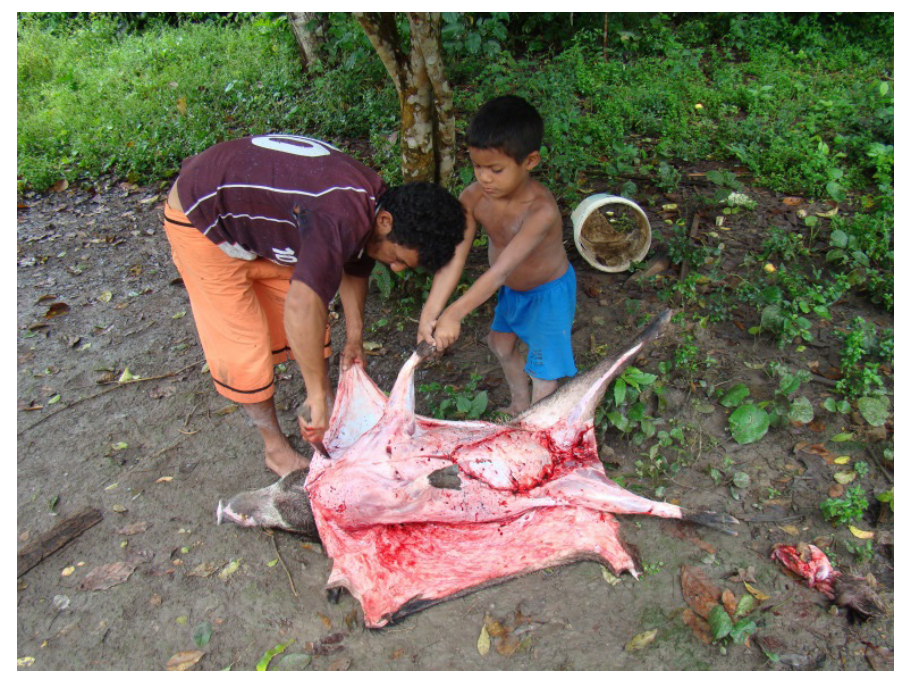

Figura 5: Pai limpando um queixada com a ajuda do filho. Foto: Flávio Barros.

A primeira técnica consiste na montagem de uma plataforma suspensa conhecida localmente como "mutá" (Figura 6), que fica numa altura de aproximadamente dois metros do chão. Esta estrutura de madeira e cipós é construída na floresta sob árvores frutíferas, que espécies de caça costumam visitar a noite para se alimentar. 0 caçador fica em silêncio apoiado nessa estrutura à espera da chegada da caça. Quando a mesma se aproxima para se alimentar dos frutos que estão pelo chão, o caçador ouve suas pisadas na mata, identifica-a com o auxílio de uma lanterna, sendo então abatida com tiro. A espera é mais utilizada no verão, pois nesta época torna-se mais fácil ouvir os sons dos animais se deslocando na serapilheira da mata, uma vez que o solo está enxuto. É aplicada principalmente para a captura de antas (Tapirus terrestris), pacas (Agouti paca) e veados (Mazama spp.).

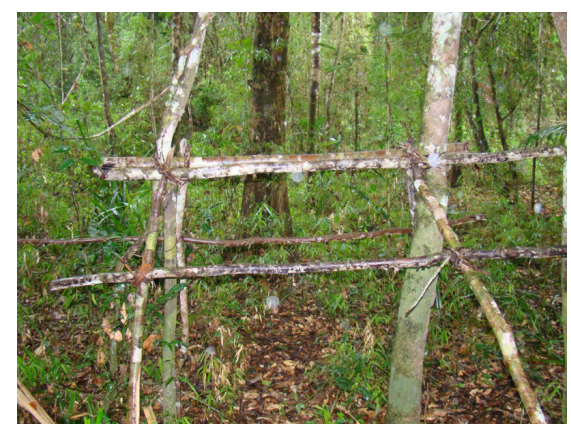

Figura 6: "Mutá" utilizado na caça de espera. Foto: FBB.

A excursão com cachorro consiste de caminhadas na mata onde os cães identificam os animais pelo cheiro ou barulho, 
encurralando-os em tocas no caso dos mamíferos de médio porte, como tatus, ou perseguindoos pela mata, como no caso dos queixadas. Em muitas situações os homens soltam gritos na mata para orientar os cães ou impedir acidentes, pois os embates destes com caças ariscas, como os queixadas, podem levá-los à morte ou deixá-los feridos gravemente. Nesse sentido, os cães exercem um importante papel na atividade de caça, os quais são, na maioria das vezes, marcados por magreza extrema. Portanto, é difícil encontrar no Riozinho do Anfrísio alguma casa que não tenha ao menos um cachorro.

A excursão sem cachorro compreende basicamente as caminhadas na mata em busca da caça, a qual pode ser identificada pelo cheiro, rastros, fezes ou outros sinais, como sons. Quando a caça é identificada, passa a ser perseguida, podendo a captura ocorrer ou não.

Em todas as situações anteriormente relatadas o uso de arma de fogo, como a espingarda calibre 20, que é a mais comum na RESEX, é utilizada para abater a presa. Na ausência de cartuchos originais - o que é mais comum ocorrer - são produzidos de forma artesanal, utilizando cera de abelha, papel, espoleta e chumbo.

As armadilhas, como a arapuca (Figura 7), são utilizadas para a apanha de pequenas aves que perambulam pelo chão. Desde a proibição da caça para fins comerciais, ainda na década de 1970, o uso de armadilhas para a captura de animais de grande porte entrou em desuso.

A lanternagem é uma técnica que consiste na procura ativa de animais na beira do rio com o auxílio de lanternas em épocas de vazantes, na passagem do inverno para o verão. Nesta época, com a diminuição dos corpos de água no interior da floresta, os animais passam a utilizar a beira do rio com maior frequência para obtenção de água, tornando-se, pois, mais susceptíveis de serem identificados e abatidos. Neste caso, utiliza-se também arma de fogo. 


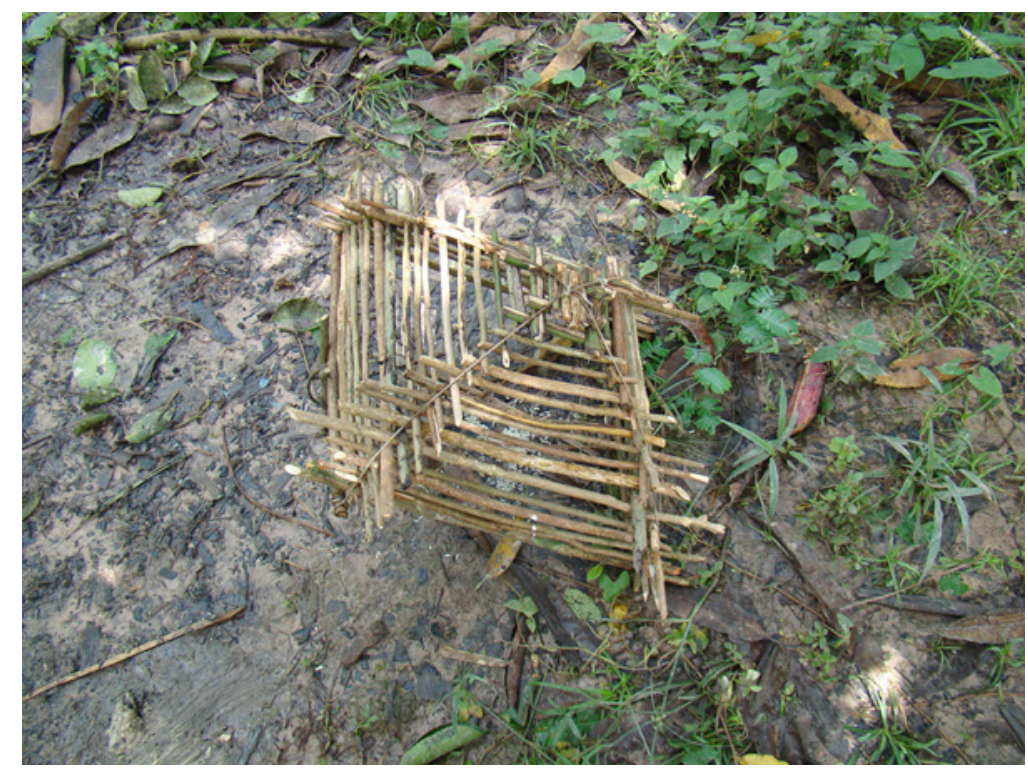

Figura 7: Arapuca, armadilha para a captura de pequenas aves. Foto: Flávio Barros.

Os encontros ocasionais são aqueles em que o caçador não tinha a intenção de caçar (Figura 8). Várias situações podem ocorrer, como: os animais "vararem" repentinamente nos quintais ou arredores das casas; durante a realização de outras atividades que não a caça podese encontrar os animais na mata ou cruzando o rio. $\mathrm{Na}$ última situação os beiradeiros podem utilizar porretes para abater a caça ao invés de arma de fogo, uma vez que a caça encontra-se em situação desfavorável quando da travessia no rio; e na ausência daquele, podem ainda afogar o animal com o auxílio de remo.
Essa situação é mais comum no inverno, quando as águas invadem parte da floresta, obrigando às vezes os animais usarem os rios para fazerem deslocamentos.

Além da espingarda, a faca (ou o facão) é outra ferramenta necessária, pois serve para executar a limpeza da caça. Em caso de sucesso na caçada, geralmente uma primeira limpa ocorre ainda na mata, com a retirada da cabeça e das vísceras, diminuindo assim o peso do animal, pois em alguns casos a distância do local da caçada até a casa é bastante longa.

Essa diversidade de formas de caçar pode ser realizada de maneira solitária ou em grupos de 
caçadores. Quando realizadas em conjunto, de amigos ou vizinhos próximos, ou parentes, são feitas com base em sociabilidades que imprimem partilha da carne, confiança, ajuda mútua e reciprocidades (MAUSS, 2003). na mata durante uma caçada, a sinergia e rapidez das ações são requisitos imbatíveis para que não haja uma tragédia. Encontros com onças são um perigo eminente e os homens da floresta não podem vacilar.

\section{Quando ocorrem complicações}

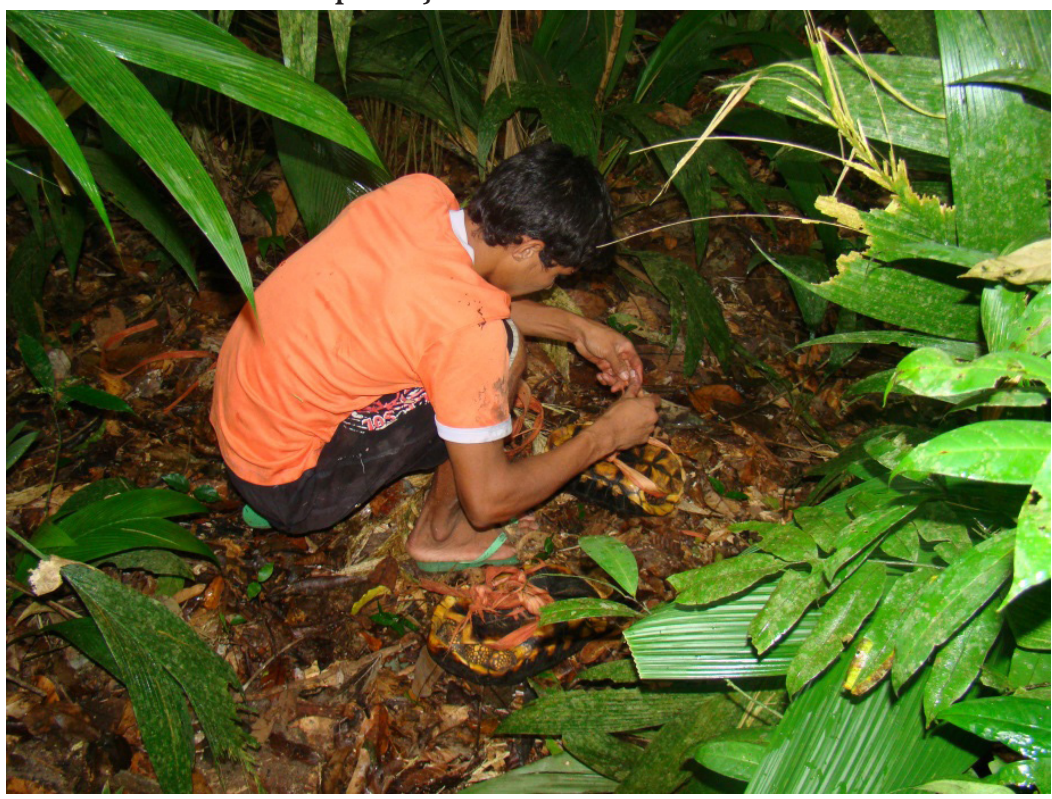

Figura 8: Caçador amarrando dois jabutis, após um encontro ocasional. Foto: Flávio Barros.

\section{Saberes e estratégias mágicas}

Os beiradeiros detêm um rico e complexo conhecimento acerca dos recursos cinegéticos, sobretudo no que diz respeito aos aspectos comportamentais, reprodutivos e ecológicos, além da identificação de cheiros, sons, tipos de fezes e pegadas específicos de cada animal. Todo esse conhecimento torna-se bastante importante para que os moradores sejam bem sucedidos na caça. Esses saberes são compartilhados ao longo do tempo com os indivíduos mais jovens, os quais precisam aprender como lidar com essa tarefa perigosa e instigante. Quando reconhecem algum comportamento peculiar ou uma "certa sabedoria" de uma determinada espécie, costumam 
dizer que o animal tem uma "ciência". Portanto, para ser bom caçador, é condição primordial conhecer essa ciência.

0 acesso à fauna útil à vida das comunidades não está condicionado apenas ao conhecimento das espécies, mas também dos ambientes onde esses animais vivem. Em cada colocação utilizam territórios de caça, os quais estão associados aos ambientes explorados pelas diversas espécies. Nesse caso, diferentes marcas são utilizadas para a caracterização e reconhecimento desses espaços, tais como lagoas, árvores de determinadas espécies, troncos caídos, caminhos, formação vegetacional, e muitos outros sinais, que geralmente são conhecidos por todos os homens da unidade familiar da colocação específica.

Um exemplo desse complexo repertório de saberes pode ser explicitado na relação que a anta (Tapirus terrestris) estabelece com uma ave de rapina da região, o gavião pien. Os interlocutores me disseram que a anta quando deseja se livrar de parasitas externos chama o gavião para catá-la quando o ouve cantar. Com efeito, quando os caçadores atentos escutam o pássaro cantar e a anta responder, consideram como certa a presença desse bicho pelos arredores. Essa observação favorece então a captura da presa. Os caçadores me contavam até com certo pesar essas histórias, pois, acabavam por impedir o prazer dos bichos. Flagraram muitas vezes a anta caída no chão, relaxada, de pernas abertas, e o pien catando ela com prazer. A primeira se livrando dos carrapatos e o segundo se fartando com o banquete. Essa festa era interrompida com a chegada do caçador, que já se encontrava por ali à espreita.

Ainda sobre a anta, me ensinaram que a fêmea só tem uma cria e apenas uma vez por ano. Quando o filhote é macho a mãe o rejeita somente quando ele a engravida, ao passo que quando a cria é fêmea, a mãe a abandona mais rapidamente. Outro exemplo de interação estabelecida é a que ocorre entre a ave nambu-azulona (Tinamus tao) e a serpente pico-de-jaca (Lachesis sp.). A ave constrói seu ninho aonde esta cobra costuma habitar, não havendo ataque desta ao pássaro e aos ovos. Por esse motivo, os 
caçadores costumam dizer que a nambu é uma ave inteligente, que dorme junto com a cobra para não ser atacada por outros animais da mata. É por esta razão que os caçadores me revelaram que sempre é bom carregar a cabecinha seca desse pássaro dentro da boroca para atrair sorte e proteção, inclusive livrando-os de encontros com cobras. Mauss (2003), em sua teoria de magia, já explicava que a parte vale pelo todo. Dessa forma, levando a cabeça do animal, acredita-se carregar sua potencialidade de conviver harmoniosamente com um ser tão temido, como a cobra. A despeito desse assunto, Descola (2006) também descreveu o uso de amuletos pelos Achuar, os quais usam dentes de boto para ajudar na caça e na pesca.

Sobre o tamanduá-bandeira (Myrmecophaga

e o "mambira" tridactyla) tetradactyla), esses animais são classificados como sendo "macho e fêmea ao mesmo tempo", pois os órgãos genitais dos machos e das fêmeas são externamente parecidos, pois ambos os sexos possuem um saco urogenital. As narrativas abaixo ilustram a riqueza de saberes acerca da fauna útil:

O macho da nambu-azulona é quem choca os ovos.

Os mutuns vivem tanto dentro da mata virgem como na beira do rio.

0 mutum anda em casal ou bandos de até 7 bichos.

Quando a anta tem um filhote macho, ele anda com a mãe até emprenhar ela. E ela não abandona o filho. Já quando a cria é fêmea, ela rejeita logo.

A anta só anda mais a noite, mas é possível ver ela de dia.

Quem come o queixada na mata é a onça.

A fêmea do caititu pare mais de uma vez por ano. Tem sempre filhote no bando o ano todo.

0 queixada é muito valente....no bando tem sempre um chefe, que é o macho mais velho. Quando estão em perigo, ele avisa ao bando, corre na frente e estrala os dentes. Quando estão com raiva bota pra riba da gente.

Certas caças, por serem "espertas", se tornam mais difíceis de serem apanhadas, como é o caso do veado. Esse bicho é complicado de ser capturado porque ele tem "muita ciência", dizem os interlocutores. Portanto, ele é dotado de sabedoria. Vejamos o que dizem sobre o assunto:

0 veado é um bicho sistemático, cabreiro...

Este ano (2009) eu só peguei 3 veados. Tem bastante veado, mas ele é escabreado. É mais arisco e 
é difícil de enxergar (Grifo meu). 0 veado é a caça mais difícil porque ele é sagaz.

0 veado é um bicho cheio de "ciência".

Atributos como cabreiro, sistemático, escabreado, sagaz, tornam, de certa maneira, esses animais humanizados, na medida em que montam suas estratégias para fugirem das emboscadas montadas pelos seus predadores, os humanos. Mas seriam eles humanos também? Diz Viveiros de Castro (1996), em torno de sua teoria do perspectivismo, que os porcos quando estão no barreiro chafurdando na lama, na verdade estão é fazendo festa, bebendo cerveja.

Diversas estratégias, além dos saberes acerca das espécies e ambientes, são empregadas para o sucesso na caça. Exemplos dessas estratégias mágicas são o uso de amuletos e a realização de rituais feitos geralmente no interior da mata. Esses processos são localmente denominados de feitiços ou simpatias. A panema (GALVÃO, 1976) é uma das motivações que levam os caçadores a empreenderem tais práticas. Em algumas situações este estado de infortúnio pode estar associado à figura da mulher grávida, como explicaram os moradores:

Se mandar um pedaço de caça pra casa do vizinho e lá tiver mulher buchuda, tem que botar sal e um pouco de pimenta malagueta. Bota só um pouco pra não perceber. Se esquecer e a mulher comer, a gente fica empanemado. Aí tem que ir pro mato fazer uma defumação e voltar por um caminho diferente (Seu Reginho, morador da RESEX).

Se pegar uma caça com cachorro bom e uma mulher buchuda comer da caça, pode atrasar o cachorro, mas nesse caso não é a mulher, mas o menino que tá na barriga é que dá o azar (Seu Domingos, morador da RESEX).

Os cachorros podem igualmente ser afetados pela panema. Nesse caso existem técnicas para eliminar esse estado indesejado, como por exemplo, dar banho com determinadas plantas, como o cipó curimbó. Cães quando estão empanemados não podem em hipótese alguma comer osso de caça abatida por outro cão sadio, sob o risco de deixá-lo no mesmo estado, ou seja, "doente".

Identifiquei

diversas estratégias empreendidas as quais se utilizam de práticas e usos de amuletos com a finalidade de melhorar o desempenho do caçador ou do cachorro, ou ainda facilitar o encontro do caçador 
com determinadas caças que ocupam lugar de preferência. Há, no entanto, alguns rituais considerados arriscados, pois oferecem perigo a quem os pratica. Passo a citar alguns exemplos.

A "maçã" de bicho trata-se de uma "bola" degordura combastante pelo que se forma na parte interna de alguns animais, como porcos, veados. Quando a caça apresenta essa "maçã", a mesma traz sorte para o caçador que a encontrou, pois os homens afirmam que animais que possuem esse tipo de estrutura são valentes e custam a morrer. Quando encontrada, ela deve ser secada e guardada pelo sortudo; depois carregada em sua "boroca"9 e ninguém pode ver, nem saber. A maçã se constitui, pois, num amuleto poderoso que vai potencializar o encontro com a caça. 0 veadinho é outro amuleto que identifiquei. Quando ocorre de um caçador abater por engano uma veada com feto ainda em estágio inicial, este é usado como amuleto de sorte. Deve ser dessecado e guardado em segredo. Em seguida o caçador coloca-o na coronha da espingarda ou na boroca. Daí em

$9 \quad$ Uma espécie de bolsa que serve para carregar os cartuchos e amuletos, caso o caçador os tenha. diante não haverá mais dificuldade de encontrar veado. Contudo, essa prática é arriscada, pois o caçador deve estar atento à contagem dos abates, marcando de 1 até 9 . Ao avistar o décimo veado, não se pode atirar, sob o risco de o caçador ficar panema e não ver mais este tipo de caça. Depois que ele avistar o décimo, mas não atirar, recomeça a contagem do primeiro.

Outra prática observada foi o uso da defumação de penas e pelos. Utiliza-se penas de vários tipos de aves, como mutum, arara, nambu, e alguns pelos de animais. Mistura-se tudo e em seguida queima numa encruzilhada, geralmente na sexta-feira de lua nova. A pessoa deve receber a fumaça originada da defumação. 0 ritual deve ser realizado em segredo e o retorno para casa deve acontecer por um caminho inverso. O macaco prego é um animal que igualmente participa das práticas de simpatia entre os caçadores. A prática recomenda atirar no maior macaco prego do bando dentro da floresta. Quando o mesmo cai morto, o caçador fica dando volta em torno do animal, mas sem tocá-lo. A partir daí 
passa-se a ter sorte e o estado de panema aos poucos vai sumir por completo. A explicação dada a mim foi que o chefe do bando é dotado de experiência singular no interior da mata, pois se trata de um líder; com efeito, ao abatê-lo e dar voltas em seu em torno, o caçador vai adquirir seus poderes.

A costela de onça foi outro amuleto de sorte relatado pelos caçadores. Seu uso implicava na recolha de uma costela quando o animal era abatido. Colocava-se a costela para secar e depois guardava na coronha da espingarda. Acreditava-se que a partir desse feitiço, se tornava mais fácil abater onça. Essa prática era empregada na época da "Pele de Gato", não sendo mais realizada hoje em dia.

O uso de plantas de poder também é fundamental nos rituais de limpeza do corpo e da alma. Dentre as mais empregadas estão a arruda e o cipó curimbó. Geralmente utiliza-se a arruda de manhã cedo. 0 caçador ao acordar de manhã esfrega essa planta aromática nos punhos e cantos dos olhos para ter sorte na caça e passar a ver melhor. Já o cipó curimbó é usado no banho.
Recolhe-se um pedaço do cipó ou raspa-se sua casca, depois mistura com a planta pião-roxo, põe de molho e em seguida toma-se o banho.

Quando ocorre de o caçador abater uma porca do mato grávida por engano, os filhotes (bacuris) são recolhidos e enterrados no local do abate. Acredita-se que os porcos ficarão visitando esse local, tornando-se mais fácil a captura de outros indivíduos pelos caçadores. Na época do inverno, como o chão da floresta fica mais úmido, os animais deixam rastros com mais frequência. É nesta altura que as pegadas dos porcos são empregadas noutra prática. A simpatia consiste na retirada da marca da pegada com um facão (um molde) e em seguida invertese a direção da pegada. Depois se faz um nó com o cipó veadinho, que serve para envolver o rastro já invertido. Acredita-se que o bando de porco ficará perdido na mata e retornará para o mesmo lugar, facilitando, portanto, o encontro dos caçadores com esses animais.

Essas práticas são repletas de simbolismos e segredos. Os objetos dos caçadores não podem ser mexidos, chafurdados por 
crianças e mesmo pelas esposas. Pessoa alguma tem autorização para manipular a boroca do caçador sem que ele permita. As cabecinhas de nambu, as "maçãs" de bicho, o feto de veado, são amuletos guardados a sete chaves; ninguém vê, ninguém sabe, apenas o caçador. Transgredir essas regras implica no risco desses amuletos não cumprirem com a sua finalidade de trazer sorte e sucesso ao caçador.

\section{Considerações finais}

Os apontamentos reunidos revelam que os saberes dos beiradeiros em torno da caça constituem um patrimônio biocultural e deveriam ser valorizados pela gestão da unidade de conservação. A fauna útil é apropriada de inúmeras maneiras, o que demonstra a capacidade de experimentação, invenção e transformação da biodiversidade. Ela é comida, remédio, utensílio doméstico, companhia. Mas essa diversidade de formas de apropriação deve ser pensada atrelada a identidade e a uma epistemologia que emerge no interior da floresta. Portanto, qualquer estratégia que aponte para a proibição da caça neste território, seria uma ameaça à soberania e aos direitos humanos. Mesmo sabendo (nós) que caçar é crime, para os povos da Terra do Meio a caça é um meio de sobrevivência física e simbólica. A caça fortalece laços sociais, é presente, dá vida ao imaginário, contribui para o controle das populações animais, gera segurança alimentar.

A ética é fator inconteste neste processo, pois não foi a academia ou os teóricos do desenvolvimento sustentável que ensinaram regras de conservação. Voltar para soltar a jabota, levar pra casa o filhote órfão, respeitar dias santos, não são meras falácias, são práticas de vida dos sujeitos. Nós, do lado de cá, é que temos muito a aprender com essas lógicas complexas que agregam natureza e cultura, pensamento e prática, cujas epistemologias frias (a ciência ocidental) ainda não dão conta de penetrar. Para esses agentes sociais não existem fronteiras, por isso, estar lá (GEERTZ, 1997) foi tão importante para ouvir os saberes e compreender, minimamente, suas lógicas.

Esse texto também teve como finalidade trazer uma contribuição 
etnográfica ao tema da caça envolvendo outras categorias sociais, uma vez que, as etnografias produzidas sobre o assunto, dentro de uma abordagem antropológica, se voltaram com maior frequência aos povos indígenas. Contudo, é fundamental dizer que as zonas de contato foram relevantes, pois, muitos dos saberes evidenciados revelam mistura, encontro, rompimento de fronteiras étnicas, pois, constantemente os indígenas e beiradeiros estão interagindo das mais diferentes maneiras.

\section{Referências}

ANTUNES, A. P.; FEWSTER, R. M.; VENTINCINQUE, E. M.; PERES, C. A.; LEVI, Taal; ROHE, F.; SHEPARD Jr.; Glenn H. Empty forest or empty rivers? A century of comercial hunting in Amazonia, Science advances, 2016. BARROS, F. B; VARELA, S. A. M.; PEREIRA, H. M.; VICENTE, L. Medicinal use of fauna by a traditional community in the Brazilian Amazonia. Journal of Ethnobiology and Ethnomedicine, 8:37, 2012.

BONAUDO, T.; LE PENDU, Y.; ALBUQUERQUE, N. Exploração da fauna silvestre na Transamazônica. In: SAYAGO, D.; TOURRANDO, J. F.; BURSZTYN, M. (Orgs.). Amazônia: cenas e cenários. Brasília: Editora da UnB, 2004, pp.101-112.

CARDOSO DE OLIVEIRA, R. 0 trabalho do antropólogo. 2ed., São Paulo: Editora da Unesp, 2006.
CONKLIN, H. C. An ethnoecological approach to shifting agriculture. Transactions of the New York Academy of Sciences, v.17, 1954, pp. 133-142.

DESCOLA, P. As lanças do crepúsculo: relações Jivaro na Alta Amazônia. São Paulo: Cosac Naify, 2006.

DESCOLA, P. Estrutura ou sentimento: a relação com o animal na Amazônia. Mana, 4(1), 1998, pp. 23-45.

DIEGUES, A. C. S. 0 mito moderno da natureza intocada. 5 ${ }^{\underline{a}}$ ed. São Paulo: Editora Hucitec/NUPAUB-USP, 2004.

ECKERT, C.; ROCHA, A. L. C. Etnografia: saberes e práticas. Iluminuras, $9(21)$, 2008, 23p.

ERIKSON, P. Animais demais... os xerimbabos no espaço doméstico matis (Amazonas). Anuário Antropológico, 2012, pp. 15-32.

FERNANDES, I. O curupira e os mitos de inversão. In: OLIVEIRA, H. (Org.). Mitos, folias e vivências. Rio de Janeiro: Mauad X/Bapera, 2014, pp.31-63.

FOOTE-WHITE, W. Treinando a observação participante. In: GUIMARÃES, A. Z. (Org.). Desvendando máscaras sociais. 2. ed., Rio de Janeiro: Livraria Francisco Alves Editora, 1980, pp. 77-86.

GALVÃO, E. Santos e visagens. São Paulo: Editora Nacional, 1976.

GARCIA, U. Ka’áWatá, “Andar na floresta": caça e território em grupo Tupi da Amazônia. Mediações, 17(1), 2012, pp. 172-190.

GEERTZ, C. O saber local. Petrópolis: Editora Vozes, 1997.

HUNTINGTON, H. P. Using Traditional Ecological Knowledge in Science: 
Methods and Applications. Ecological Applications, 10(5), 2000, pp. 12701274.

MALINOWSKI, B. Argonautas do Pacífico Ocidental: um relato do empreendimento e da aventura dos nativos nos arquipélagos da Nova Guiné Melanésia. São Paulo: Abril Cultural, 1978.

MAUSS, M. Sociologia e Antropologia. Tradução: Paulo Neves. São Paulo: Cosac \& Naif, 2003 [1872-1950].

PERES, C. A. Synergistic effects of subsistence hunting and habitat fragmentation on Amazonian Forest vertebrates. Conservation Biology, 1490-1505, 2001.

PRADO, H. M.; MURRIETA, R. S. S. A etnoecologia em perspectiva: origens, interfaces e correntes atuais de um campo em ascensão. Ambiente e Sociedade, 18(4), 2015, pp. 139-160.

SANTOS, B. S.; MENESES, M. P. G. de; NUNES, J. A. Introdução: para ampliar o cânone da ciência: a diversidade epistemológica do mundo.In:SANTOS, B. S. (Org.). Semear outras soluções: os caminhos da biodiversidade e dos conhecimentos rivais. Rio de Janeiro: Civilização brasileira, 2005.

SERVICE, E. R. Os caçadores. Coleção "Curso de Antropologia Moderna". Rio de Janeiro: Zahar editores, 1971. TOLEDO, V. M.; ALARCÓN-CHÁIRES, P. La Etnoecología hoy: Panorama, avances, desafíos. Etnoecológica, 9 (1), 2012, pp. 1-16. TOLEDO, V. M.; BARRERA-BASSOLS, N. Etnoecologia: uma ciência pósnormal que estuda as sabedorias tradicionais. Desenvolvimento e Meio Ambiente, 20, 2009, pp. 31-45.

VIVEIROS DE CASTRO, E. Araweté: o povo do Ipixuna. São Paulo: CEDI, 1992.

VIVEIROS DE CASTRO, E. Os pronomes cosmológicos e o perspectivismo ameríndio. Mana, 2(2), 1996, pp. 115144.

WILLERSLEV, R. Percepções da presa: caça, sedução e metamorfose entre os Yukaghirs da Sibéria. Anuário Antropológico, 2012, pp. 57-75. 